\title{
THE EFFECT OF IMPLEMENTATION OF SUPERVISOR SUPERVISION COMMUNICATIONS ON IMPROVING THEMATIC LEARNING IN SD GUGUS II, KELARA DISTRICT, JENEPONTO REGENCY
}

\author{
Kamaluddin \\ Alauddin State Islamic University of Makassar, Indonesia
}

\begin{abstract}
Communication is essential in life. No exception for supervisors should have communication skills. In Jeneponto Regency, the application of the thematic learning model requires supervisors who have communication skills. The research shows a positive effect on increasing thematic learning in SD Gugus II, Kelara District, Jeneponto Regency. The magnitude of the impact is $25,90 \%$, and other variables determine the rest.
\end{abstract}

Keywords: Supervision Communication; Thematic Learning

\section{BACKGROUND}

Improvement of human resources (HR) for learners is a priority target for development. Because of that, learners are expected to prepare themselves well to move on with their lives. The preparation is done through education.

Improving the quality of education becomes the responsibility of all parties involved in education, especially for elementary school educators, which is essential in basic education. The educator at level Elementary school is the person who plays the most role in creating mare resources quality people who can compete in the era of technological development. Educators in every learning always use approaches, strategies, and learning methods to understand the material.

According to the author's observations in the implementation of classroom learning, the use of varied learning models is still very low, and educators tend to use conventional models in every lesson they do. This problem may be caused by less mastering of the learning model. At the same time, mastering the learning model is needed to improve educators' professional abilities to become professional educators, according to Sardiman AM (2017: 132).

Based on with things the government, through the National Standards Agency Education (BSNP), stipulates a thematic approach as an approach learning to do on learners Elementary school, especially in learners low class (class)s I to III). According to BSNP (2006:35), the determination of thematic approach to learning in elementary school due to the development of participants students in the lower grades of Elementary School, are generally at the level a development that still sees everything as one wholeness (holistic) and only able to understand the relationship between concepts in a simple way. Therefore, the learning process still depends on concrete objects and direct experience. Learning which done by separating subjects will lead to underdeveloped children thinking holistically and making it difficult for them to relate concepts with their real lives every day. Some of the weaknesses of educators in carrying out thematic learning are as follows:as follows: 1) Educators still do not understand the 
concepts of governmentthematic lessons that include: characteristics, signs, and principles of theme selection; 2) Educators are still not able to arrange thematic learning tools, learning models, and so onstrategies, steps and procedures for implementing thematic learning. 3) Educators have not been able to overcome the problems that exist in thematic learning, including: integrated learning methods in early grades, setting lesson schedules, assessingian, and the use of source books.

From these conditions, research is needed on the thematic learning approach in improving the quality of learning and learning achievement of learners. The high and low quality of learning is the result of a process, namely teaching and learning activities. In addition, the quality of learning is also influenced by the conditions of the people who involved in the process and the way they work together. Quality needs to be treated as a criterion dimension that serves as a benchmark in professional development activities both related to the business of organizing educational institutions and learning activities in the classroom. It is necessary because a nation will compete in the international arena if it has an advantage (excellence) recognized by other nations. The success of the implementation of thematic learning is largely determined by all parties, especially the education supervisors at the elementary school level. Therefore research about supervisory supervision communication at the time of learning planning, implementation learning, and evaluation of learning, significantly to improve thematic learning in Elementary school in reading, writing and arithmetic, is indispensable.

Based on these thoughts, the problems in this research are: How influence supervisory supervision communication has an effect on increasing thematic learning in Cluster Elementary School II K. Districtelara districts Jeneponto? The purpose of this study was to determine the effect of implementation supervisory supervision communication on improving thematic learning in elementary school Group II K . Districtelara Jeneponto Regency.

\section{THEORETICAL STUDY}

\section{A. Supervisor Supervision Communication}

The defenition of communication by Wiryawan and Noorhadi in Irawan et al (1994:69) is the process of conveying ideas from one person to another. Meanwhile, based on the Lasswell paradigm in Effendy (2005:10) communication is the process of delivering pesan by communicator to the communicant through the media that causes certain effects. Communication has four main functions in a groupor organization that is: 1) The control function, namely communication serves to control member behavior in several ways; 2) Motivation. Communication maintains motivation by providingexplain to employees what to do how well they do it, what can be done, how well they do it and to menimprove performance if moderate below standard ;3) Emotional statement. Communication is a way of expressing emotions and fulfilling social needs; 4) Information. FunctionThis relates to his role in facilitate decision making. The function gives information for individuals or groups to make decisions by including data to identify and evaluate options (Robbins, 2012:146).

In communicating learning to learners teacher role very decisive, namely skilled in communication, being straightforward, intelligent, authoritative, nurturing, and encouraging learners. Besides that, the teacher has a lot of knowledge and is not old last night from the learners, have soul socio-cultural (Soejana, 2007: 108).

The teaching and learning process will not be separated from the interaction. For the learning objectives to be achieved, the interaction must be supported with effective 
communication. Educators can use communication in several forms, and those are: 1) Verbal information submission; 2) Submission of information in writing; 3) Communication through electronic media; 4) Communication in group activities.

For the implementation of educational activities, supervision has a very important role very important. Adams and Dickey (1999:2) supervision is a program that plans to improve teaching. The essence of the supervision program is essential to improve teaching and learning. This program can be successful if the supervisor has skills in an efficient way of working in collaboration with other people, namely educators and other education personnel. In the Dictionary of Education, Good Carter (Sahertian, 1982: 18) gives the definition The meaning of supervision is as follows: Supervision is the effort of education officers in leading teaching staff, including educators and other education personnel in improving teaching, stimulating, selecting job growth and educator development and revising educational goals, teaching materials and teaching methods, and evaluation of teaching.

From the definition, It can be understood that: 1) Educational supervision is expected to be able to grow the profession and personal educators. 2) In educational supervision, they do not look for mistakes but try to help educators to be able to find and solve every problem they face. 3) Supervision is an effort to assist and serve educators to improve professional competence. 4) Indirect supervision is directed to students but to educators. 5) Supervision is not directive but more consultative in nature, namely providing motivation, advice and guidance.

Thus, the essence of supervision is a process of guidance from the superiors(supervisors) to educators and personnel as administrative managers. Supervision activities are carried out by supervisors who act as mentors to improve teaching and learning situations better, with skill and the ability to lead and the authority or competence and professionalism in their respective fields. Of course, the efforts made must be humane and democratic without favouritism, have quality and loyalty, be disciplined, be responsible, and be accountable.

Based on the limitations stated above from several supervision experts, it can be concluded that educational supervision (teaching) is the provision of motivation and professional guidance to educators as an effort to increase abilities and skills in the teaching and learning process. Especially abilities and skills that have to do with the disciplines they practise or the expertise they have. Supervision tasks carried out in class on Basically, the principal and supervisor must directly see the learning process carried out by educators in the classroom. Class observation activities are a form of supervision carried out by school principals and supervisors to see the implementation of the process in the classroom, whether the learning process is following the lesson plan (RPP) and has referred to the learning syllabus made by the educator or not. Similarly, whether composing or writing learning indicators are by the rules of indicator writing, namely already referring to basic competencies and existing competency standards, or whether educators have taught using learning media following the requirements for using learning media. For example, whether the media is under the learning material, whether the media is by the level of development of students, whether it is under the environment of students, whether it can attract students' interest, whether the media is not discriminatory The implementation of class supervision can also be carried out to find out the techniques being implemented by educators to find out whether the communication techniques used by educators in learning, in this case, the learning methods used by educators are following the level of intellectual development of students or not. There are many things 
that the principal or supervisor can obtain in carrying out classroom supervision, which aims to assist educators in improving their teaching abilities or to assist educators in improving their professional competencies. The results of supervision are expected to be the basis for supervisors and principals in preparing follow-up programs from the implementation of supervision. A school principal or supervisor is expected to be able to develop a realistic follow-up program so that the weaknesses found in supervision can be overcome.

Purpose and function are quite difficult to distinguish because it often happens that an object can be explained in terms of purpose and function. Therefore, it can be briefly stated that supervision is a goal when viewed from what supervision wants to achieve. But supervision is a function if it is seen as part of the organization of a school. So the purpose and function of supervision are closely related. They both concerned about the same thing. These two things are distinguished so that the information provided will be complete.

The purpose of supervision takes into account several factors that are specific in nature so that it will be able to help find and determine more effective supervision activities. Of course, we are not talking about the effectiveness of activities without a clear purpose. Sahertian $(1982,24)$ suggests as follows: 1) Helping educators to see clearly the goals of education; 2) Assist educators in guiding students' learning experiences; 3) Assisting students in using the sources of learning experiences; 4) Assisting educators in using methods and tools, as well as being able to carry out their duties; 5) Assisting educators in meeting the learning needs of students; 6) Assist educators in assessing the learning outcomes of students' progress and the results of the learner's work; 7) Assist educators in fostering professional and work morale for educators in the context of personal and position growth; 8) Helping junior educators in schools, so that they feel happy with the task at hand obtained; 9) Help educators to make adjustments more easily to society and ways to use community resources; 10) Helping educators, so that time and energy are fully devoted to fostering the teaching and learning process.

\section{B. Thematic Learning}

Determination of thematic approach in learning in low grade by The National Education Standards Agency (BSNP) cannot be separated from developments in integrated learning. Considering the development of an integrated approach in Indonesia, the learning model that is being studied and developed is the integrated learning model proposed by Fogarty (1990). The integrated learning model proposed by Fogarty originated from the concept of an interdisciplinary approach developed by Jacob (1989).

The characteristics of this thematic learning, according to Tim Pedeveloping PGSD (1997:3-4), are (1) holistic, a symptom or event which is the centre of attention in the thematic lessons are observed and studied from several subjects at once, not from a compartmentalized point of view. (2) meaningful, the study of a phenomenon from various aspects, allows the formation of a kind of link between schemata owned by learners, which in turn, will have a meaningful impact on the material studied; (3) authentic, thematic learning allows learners understand firsthand the concepts and principles to be studied. (4) Active, thematic learning is developed based on the approach Where's the inquiry? Learners actively involved in the learning process, from planning, implementation, to the evaluation process. 
The thematic learning model is a model learning that development begins by determining a particular topic as a theme or theme the central topic; after the theme is determined, the theme is used to determine the basis of the sub-themes of other related subjects. The teacher can do the determination of the theme through conceptual themes quite common but productive. It can also be determined by negotiation between the teacher and learners or by means of peer discussion learners. Alwasilah et al. (2008:16) mention that the theme can be developed based on the interests and needs of students who move from the closest environment of students and then move to the farthest environment of students.

The implementation of teaching and learning process activities as a core element of learning activities are adjusted to the signs that have been prepared in the previous planning. The implementation of thematic learning is applied to three learning steps. These are (1) The initial activity aims to attract students' attention, foster student learning motivation, and provide references or signs about the learning to be carried out. (Sanjaya, W., 2006:41); (2) Core Activities is the main activity in the learning process. Where to discuss themes and sub-themes through various learning activities using multiple methods and media so that learners have a meaningful learning experience, at the time of presentation and discussion of the theme, the teacher in the presentation should play a more role as a facilitator (Alwasilah: 2008); (3) Final activity, can be interpreted as an activity carried out by the teacher to end the lesson with the intention of providing a comprehensive picture of what students have learned and its relationship to previous experience, knowing the level of success of students and the success of teachers in implementing the learning process.

Evaluation in thematic learning is no different from evaluation for conventional learning (Raka Joni 1996:16). Therefore, all the principles that need to be heeded in conventional learning also apply for thematic learning assessment. The difference is in the evaluation of thematic learning, emphasizing aspects of the process and effort of forming the accompaniment effect (nurturant effect) likeability cooperation, tolerance, etc. Prating learners in grades I and II SD have not followed the assessment rules such as eyes another lesson. Considering that the first graders of elementary school are not all fluent in reading and writing writing, then assessment in class I is not emphasized on selfassessment written.

\section{RESEARCH METHODS}

Based on the form of the problem, this type of research includes quantitative descriptive research. The approach used in this study is an educational communication approach. Research This will be held from July to September 2020. This research took place at SD Cluster II, Kelara District, Jeneponto Regency. The population in this study were all elementary school teachers for the early grades, Kelara district, Jene Regencyponto for the 2020/2021 academic year, totalling 75 people from 25 elementary schools, consisting of 11 public elementary schools, 13 presidential instructions, and one small elementary school. Based on the population, because the population can be detected in the study, the sample of this study is always the spirit of the Elementary School teacher for the Early Grades of Cluster II Kelara District, Jeneponto Regency The academic year 2020/2021, totalling 27 people of 9 elementary schools consisting of 4 public elementary schools, four presidential instructions, and one small elementary school. To obtain data in This research requires tools data collector as 
follows: 1) Documentation Techniques; 2) Questionnaire technique; 3) Interview technique. The data obtained from the research results were analyzed using descriptive statistical analysis. Activities analysis is carried out through 1) descriptive analysis and 2) Inferential statistical analysis was carried out to test the research hypothesis whether or not supervisory supervision communication affected the improvement of thematic learning in SD Cluster II, K District.in Jeneponto Regency.

\section{IV.FINDINGS}

Based on the regression analysis that has been carried out, the value of $\mathrm{a}$ is where the value $(Y)=66.695, B_{1}\left(\right.$ regression coefficient $\left.X_{1}\right)=1.329, B_{2}$ (regression coefficient $\left.\mathrm{X}_{2}\right)=(-0.719), \mathrm{B}_{3}\left(\right.$ regression coefficient $\left.\mathrm{X}_{3}\right)=1.018, \mathrm{~B}_{4}\left(\right.$ coefficient regresi $\left.\mathrm{X}_{4}\right)=0.961$, or expressed by the regression equation as follows:

$\hat{Y}=66,695+1,329 X_{1}+(-0.719) X_{2}+1.018 X_{3}+0.961 X_{4}$.

The four regression found the regression coefficient $X_{1}, X_{2}, X_{3}$, and $X_{4}$ with the coefficient of determination of 69,284 . Thus, together the variables $X_{1}, X_{2}, X_{3}$, and $X_{4}$ causes a change in the value of Y by 0.2590 or by $25.90 \%$.

From the results of the analysis, it also found that in influencing each sub variable, it gives a relative contribution of:

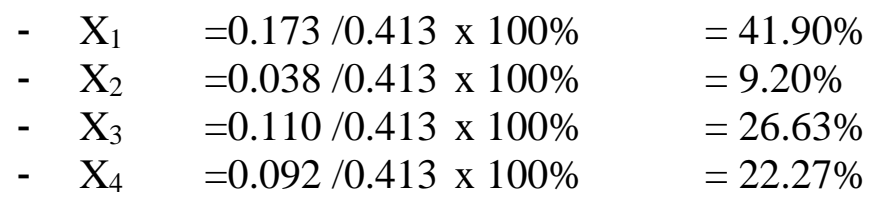

While the effective contribution is:

$$
\begin{array}{llll}
-\mathrm{X}_{1} & =0.173 / 0.413 \times 25.90 \% & =10.85 \% \\
- & \mathrm{X}_{2} & =0.038 / 0.413 \times 25.90 \% & =2.39 \% \\
-\mathrm{X}_{3} & =0.110 / 0.413 \times 25.90 \% & =6.90 \% \\
-\mathrm{X}_{4} & =0.092 / 0.413 \times 25.90 \% & =5.76 \%
\end{array}
$$

Based on the analysis results above, it can be concluded that supervisory communication Supervisors in compiling messages, delivering conveying messages, providing feedback, and conducting follow-up programs positively affect increasing thematic learning at SD Gugus II, Kelara District, Jeneponto Regency. Thus, the research hypothesis is accepted, namely: "There is a positive influence spirit towards the improvement of thematic learning at SD Cluster II, Kelara District, Jeneponto RegencyThe summary of the results of the multivariate analysis can be seen in the following table:

Tabel. 1

The results of multivariate analysis between variables $\mathrm{X}_{1}, \mathrm{X}_{2}, \mathrm{X}_{3}$, and $\mathrm{X}_{4}$ against $\mathrm{Y}$

\begin{tabular}{|l|c|c|c|c|c|}
\hline Variable & $\begin{array}{c}\text { coefficient R } \\
\text { Against Y }\end{array}$ & $\begin{array}{c}\text { Regression } \\
\text { against Y }\end{array}$ & $\begin{array}{c}\text { Y } \\
\text { intercept }\end{array}$ & $\begin{array}{c}\text { reactive } \\
\text { donation }\end{array}$ & $\begin{array}{c}\text { Effective } \\
\text { donation }\end{array}$ \\
\hline $\mathrm{X}^{1}+\mathrm{X}^{2}+$ & 0.509 & 0.1730 .038 & 0.509 & $100 \%$ & $25.90 \%$ \\
$\mathrm{X}^{3}+\mathrm{X}^{4}$ & & 0.1100 .092 & & & \\
& & & & $41.90 \%$ & $10.85 \%$ \\
$\mathrm{X}^{1}$ & & & & $9.20 \%$ & $2.39 \%$ \\
$\mathrm{X}^{2}$ & & & & $26.63 \%$ & $6.90 \%$ \\
$\mathrm{X}^{3}$ & & & & & \\
\hline
\end{tabular}




\begin{tabular}{|l|l|l|l|l|l|}
\hline $\mathrm{X}^{4}$ & & & & $22.27 \%$ & $5.76 \%$ \\
\hline
\end{tabular}

Source: results primary data processor

\section{CONCLUSION}

From the study results, it can be concluded that there is a positive effect on increasing thematic learning in SD Cluster II, Kelara District, Jeneponto Regency. The magnitude of the effect is $25,90 \%$, and the rest is determined by another variable.

\section{VI.SUGGESTIONS}

From the conclusions that have been stated, it is recommended for supervisors to improve communication skills because communication skills greatly support or improve the implementation of thematic learners in particular and other educational activities in general.

\section{BIBLIOGRAPHY}

Adam, HF, and Dickey, FF Principles of Supervision. New York

Arikunto, Suharsimi, 1999. Basics of Educational Evaluation. Jakarta: Burni Aksara

Effendy, Onong Uchyana. (2005). Science Communication Theory and Practice. Bandung: PT. Teenagers Rosdakarya

Alwasih, Hesty, Implementation of learning model thematic - Documents Transcript , Learning Integrated (www.slideshare.net/naninurnaeni/ learning terpadu) , Learning model Thematic - Tera Indonesia Development Team for PGSD and Master of Education Basic (www.scibd.com/doc/ 25002500/64-hesty)

Raka, TJ (1996). Learning Integrated. Jakarta : Department Education and Culture, Directorate General Education High

Sahertian, 2010. Principlep and Educational Supervision Techniques. Surabaya National Business.

Sanjaya, W. (2006). Strategy Learning Oriented Process Standard Education.Jakarta : date Prenada Media.

Sudjana, Nana. 2004.Fundamentals of the Teaching and Learning Process. Bandung New Light Algesimfo

Sukayati, 2004. Learning The Thematic In Elementary School Is Applied from Integrated - PPPG Mathematics Yogyakarta. 